\title{
Remembering Women in the Struggle
}

\author{
Mary McArdle \\ Maghaberry Womens Prison
}

As women, we are often reminded that our contribution to the struggle has gone largely unnoticed and unrecorded. We were delighted therefore that the theme for Prisoner's Day 1995 was to be 'Women in the Struggle' and we were honoured to be able to make our own contribution to the events. I, along with Mary Ellen Campbell, had the privilege of attending to represent women POWs. The event attracted ex-prisoners from all parts of the country including Bronwyn McGahan from Tyrone, the most recently released woman POW from Maghaberry jail. Also present for the occasion were Donna Maguire and Póilín Uí Chatháin, both of whom were recently released from jails in Germany.

The day began with a volleyball match between Armagh and Maghaberry, an enjoyable event for both the players and the spectators. The winning trophy, in memory of Rosaleen Russell, a tireless worker on behalf of women's rights who died earlier in the year, was presented to the Maghaberry women who were victorious on the day.

At lunchtime, Tar Anall, the new drop-in centre for ex-POWs and their families, was officially opened. Maura McCrory gave a short speech after which Pam Kane and Briege Norney unveiled the opening plaque. Maura outlined the importance of Tar Anall and invited everyone to avail of its services. Briege then spoke of the plight of prisoners in English jails and the hardships endured by their families.

After the formalities were dispensed with, those who had gathered for the opening mingled informally before moving next door into the Felons' Club which hosted a variety of prison-related exhibitions. Among these exhibitions was a photographic display representing the various roles women have played throughout the war. Cell-like structures had also been created to show different phases of prison struggle with detailed information provided on each particular chapter. The traditional array of POW handicrafts were also on display. One poignant aspect of the exhibition was the display which included personal letters belonging to Tom Williams as well as newspaper cuttings about his case and trial. Also included in this display was the shirt Tom wore on the day of his arrest.

A quilt made by Irish Women's groups, which was taken to the UNWomen's Conference in Beijing, was also featured. The theme of this quilt was 'Women's Rights are Human Rights' and the women POWs in Maghaberry had contributed a panel to it. A massive poster expressing solidarity with the 
Basque prisoners seemed particularly appropriate with a large Basque delegation in attendance.

A video entitled 'What Did You Do in the War Mammy?' which documented the experiences of republican women through several decades, was one of the highlights of the day. Full credit for this excellent production goes to the Falls Women's Centre for their hard work and persistence which, despite this being their first venture into the world of film making, produced this highquality documentary. Narrated by Caral Ni Chulainn, the video was a clear testimony to the changing role of women in the republican struggle and had Eileen Brady, a long-time activist, lamenting the fact that she was not nineteen again.

After the showing of the video, several women shared a panel and spoke of their experiences of imprisonment, which included internment, the no-wash protest and hunger strikes in Armagh, the opening of Maghaberry jail, and the present-day conditions faced by women POWs. Pamela Kane talked of her experiences in Mountjoy and Limerick jails, outlining the hardships and isolation associated with being the only female IRA prisoner in the twenty-six counties. There then followed a question and answer session, chaired by Una Gillespie, that raised many pertinent questions in relation to women's struggle.

The evening function proved to be a moving event. A statement, paying tribute to the sacrifice of the women who had given their lives during the struggle, was read out on behalf of the women POWs in Maghaberry. It further acknowledged the roles that women have played over the years and called on this potential to be utilised in all future initiatives.

Presentations were then made to Louise McManus, Anne O'Sullivan, and Lily Fennell for their selfless work on behalf of the republican movement. Other presentations were made to ex-prisoners Bronwyn McGahan, Pamela Kane, Póilín Uí Chatháin, and Donna Maguire. Madge McConville and Greta Nolan, both of whom were arrested with Tom Williams, were presented with framed pictures in recognition of long years of dedication to the republican cause. Madge and Greta then unveiled a cross in memory of the dead volunteers and presented it to Liam Shannon who accepted it on behalf of the Felons' Club.

A colour party led by a lone piper then entered the hall, their flags lowered as a mark of respect, and a minute's silence was observed. The sombre mood that had descended upon the proceedings created a fitting atmosphere for the presentation ceremony for the families of our fallen women comrades. The family of each volunteer was presented with a plaque that contained a small photograph of their loved one. I was touched by the dignity and courage of the families whose grief, despite the passing of time, is still so apparent.

Finally the day was at an end. It had been a long day and after months of research, hard work, and effort it was, despite its sadder moments, a day that republican women could be proud of. What we, as POWs, had wanted most of 
all was to ensure that the role of women in our struggle was not forgotten. We especially wanted to honour our comrades who died for Irish freedom and to offer our support to their families. We sincerely hope that we achieved that.

Presentations were made to the families of the following comrades who have died:

Patrica Black

Margaret Mcardle

Maura Drumm

Rosemary Bleakley

Ann Parker

Annmarie Pettigrew

Mairead Farrell

Bridie Dolan

Dorothy Maguire

Maura Meehan

Eileen Mackin

Laura Crawford

Catherine Mc Gartland

Sheena Campbell

Ethel Lynch

Julie Dougan

Bridie Quinn

Pauline Kane

Vivienne Fitzsimmons 